\title{
Labial hypertrophy as a cause for vulvae pruritis
}

\author{
Arshiya Firdaus*, Rachna Chaudhary
}

Department of Obstetrics and Gynecology, LLRM Medical College, Meerut, Uttar Pradesh, India

Received: 28 January 2020

Accepted: 28 February 2020

\section{*Correspondence:}

Dr. Arshiya Firdaus,

E-mail: arshi2210@gmail.com

Copyright: (C) the author(s), publisher and licensee Medip Academy. This is an open-access article distributed under the terms of the Creative Commons Attribution Non-Commercial License, which permits unrestricted non-commercial use, distribution, and reproduction in any medium, provided the original work is properly cited.

\begin{abstract}
Labia minora hypertrophy is a relatively uncommon surgical condition being popularised in the realm of vulvovaginal plastic surgeries. Apart from the unaesthetic appearance of the hypertrophied minora, these cases are also associated with itching, hygiene problem, pain while sitting down, sports activities, difficulty in wearing tight clothing, bleeding and discomfort while or after sexual intercourse, social embarrassment, insecurity and psychological diminution of confidence and self-esteem. In a country like India, due to sociocultural reasons, patients hesitate to consult a doctor for such deformities. Most of the patients suffer in silence for years. Although common in the west, very few surgeons in the country perform this simple and rewarding surgery. Here, presenting a case of married women of reproductive age group presented to the study side with complains of severe vulvar itching, the cause of itching was labia minora hypertrophy.
\end{abstract}

Keywords: Labiaplasty, Labia minora hypertrophy, Vulval pruritis

\section{INTRODUCTION}

There is an increasing concern amongst the women and girls about the appearance of their external genitalia. Many women and adolescent girls present with labia hypertrophy. Labia minora hypertrophy describes labia minora becomes thick and stick out more than labia majora. ${ }^{1}$ Most women will never have a problem, if there is mild labial hypertrophy, it goes unnoticed. Labia minora is however much more sensitive than labia majora, so enlarged minora can cause few difficulties.

\section{CASE REPORT}

A woman of age 26 years old presented in this gynae OPD with complain of off and on severe itching in her genital area since 5 years. She was P2L2A2 both the children were from caesarean section. Her menstrual cycle was regular with no menstrual complains. No complains of dysuria, dyspareunia, or discharge per vaginum. The labia sticking to the undergarments made her feel very uncomfortable throughout the day. The itching was severe that disturbed her night sleep. On clinical examination, her labia minora was found to be thickened and enlarged more than $5.5 \mathrm{~cm}$ from the free edge of the labia majora (Figure 1 and 2) (Type 3: Franco's classification; severe hypertrophy: Ricci and Pardo classification) (Tables 1 and 2). ${ }^{2,3}$ The labia were darkly pigmented and thickened consistent with chronic irritation. Slight redness in fourchette region due to itching. The rest of the external genitalia was within normal limits. She was sexually active with no history suggestive of trauma or assault not using any barrier method of contraceptive which could be the cause of vulval itching (like allergy to material of condom used and lubricating jelly) other cause of vulvitis was also ruled out. The labiaplasty was performed under spinal anesthesia in lithotomy position. Skin and subcutaneous tissues in the labia minora were found to be hyperplastic. Extended linear excision was performed. As she was young and sexually active patient, care was taken not to distort the clitoral area and the tissue around it. The excision planned was so that later it would be covered by itself by labia majora mimicking the normal anatomy. 
Interrupted Monocryl 1-0 sutures were applied after hemostasis. Tight $\mathrm{T}$ bandage and vaginal padding was done for 24 hours (Figure 3). After 24 hours, the patient was advised to clean the genitalia, sitz bath and application of antiseptic ointment was advised. Postoperatively, the patient complained of moderate pain and was prescribed analgesics and cold fomentation. There was slight induration and redness of the region, which subsided in 4 days. Post-operative recovery was uneventful (Figure 4).

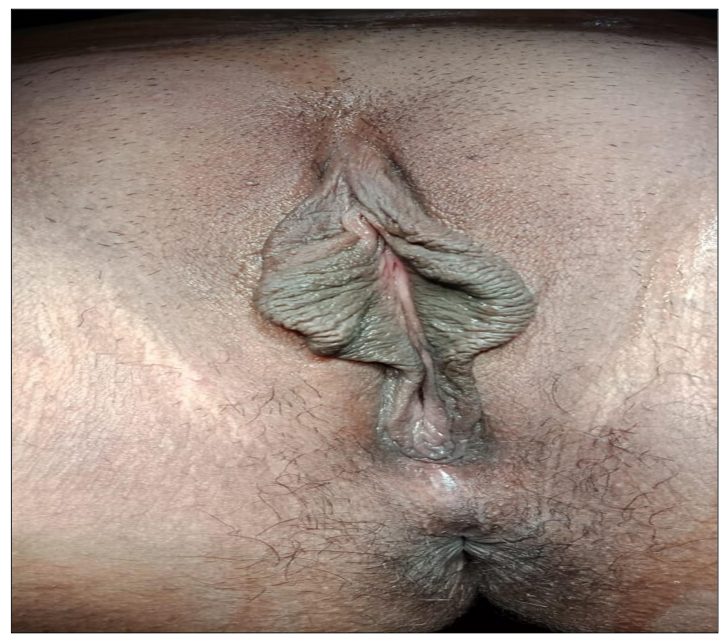

Figure 1: Pre-operative view of labia minora hypertrophy.

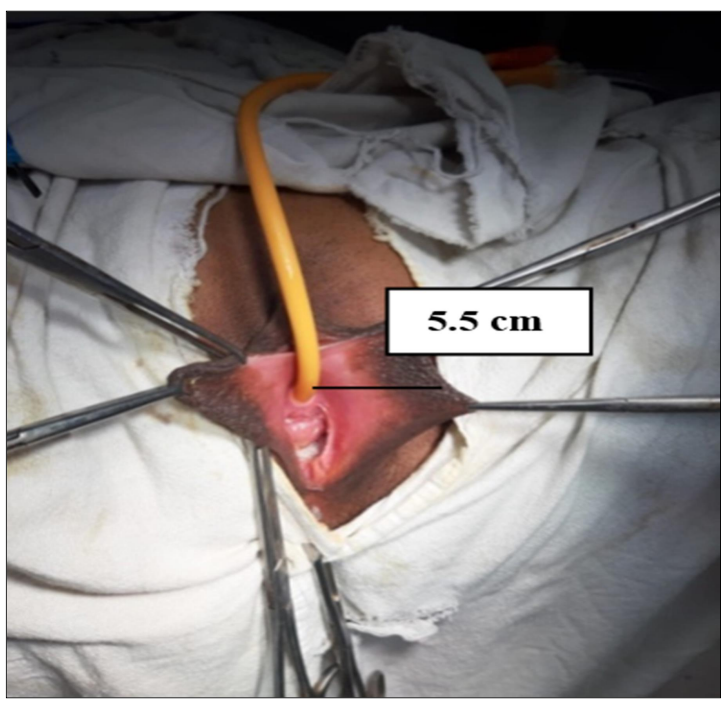

Figure 2: Size of labia minora measuring $5.5 \mathrm{~cm}$ in its width.

\section{DISCUSSION}

Hodgkinson and Hait first described labia minora hypertrophy in 1984; though description regarding circumcision of labia minora and clitoris has been mentioned vaguely in many old scriptures. Hence, whenever a surgeon in a developing country like India diagnoses a labia minora hypertrophy it should be addressed properly, and relevant procedure should be carried out to relieve the patient from distressing symptoms. ${ }^{4}$ Although no standard consensus has been established yet to classify labia minora hypertrophy; many do exist depending on the size and severity of the hypertrophy (Table 1 and 2).

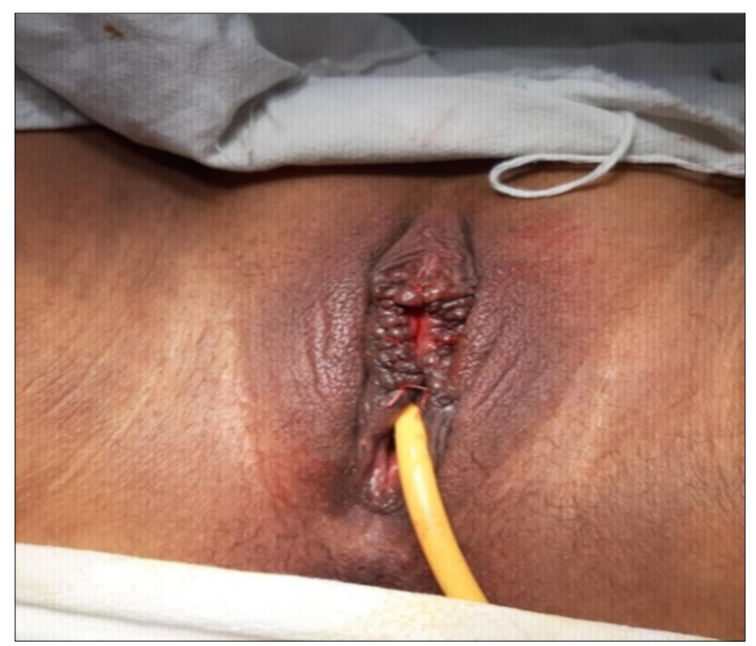

Figure 3: Linear excision of labia minora.

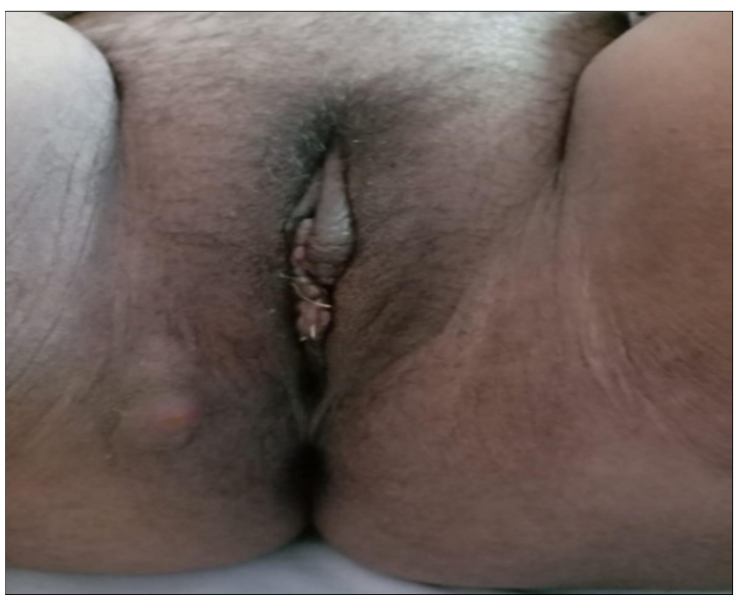

Figure 4: After 4 weeks postoperative result.

Table 1: Franco classification of labia minora hypertrophy.

\begin{tabular}{|l|l|}
\hline Type & Labial width $(\mathrm{cm})$ \\
\hline 1 & $<2$ \\
\hline 2 & $2-4$ \\
\hline 3 & $4-6$ \\
\hline 4 & $>6$ \\
\hline
\end{tabular}

Arbitrary landmarks taken in these measurements make it difficult to diagnose hypertrophy on a standard scale. Some have measured size from midline horizontally, and 
some have measured from free edge. It is indeed of great importance to include patient's own symptoms in the diagnosis. Surgical decision should largely be dependent on labia size as well as symptoms addressed by the patient.

Table 2: Ricci and Pardo classification of labia minor hypertrophy for surgical correction.

\begin{tabular}{|l|l|}
\hline Type & Labial width (cm) and character \\
\hline $\begin{array}{l}\text { Lacking true } \\
\text { hypertrophy }\end{array}$ & $\begin{array}{l}\text { Up to } 2 \mathrm{~cm} \text { and no zone of greater } \\
\text { growth but with morphological } \\
\text { defect such as asymmetry }\end{array}$ \\
\hline $\begin{array}{l}\text { Moderate true } \\
\text { hypertrophy }\end{array}$ & $\begin{array}{l}2-3 \mathrm{~cm} \text { with zones of greater } \\
\text { growth }\end{array}$ \\
\hline $\begin{array}{l}\text { Severe true } \\
\text { hypertrophy }\end{array}$ & $\begin{array}{l}>4 \mathrm{~cm} \text { with or without zone of } \\
\text { greater growth/hypertrophy }\end{array}$ \\
\hline
\end{tabular}

A number of studies have been published in context to labia minora hypertrophy and their management, but only a few have addressed the occurrence of hypertrophy in adolescent age and most of their patients fall in 20-40 age group. ${ }^{5,6}$ Although age is not a criterion for labiaplasty, most of the surgeons refrain from doing it at an early age. ${ }^{7}$ Case patient was an 26-year-old having severe itching in vulva, which was worse at night that disturbed her sleep which is rare. There was no complain of dysuria, or discharge per vaginum.

No skin disease was identified. Antiallergic medicines were given and deworming was done with albendazole. No relieve occurred despite maintaining perineal hygiene suggestive of an idiopathic, isolated and abnormal morphology of the labia.

\section{CONCLUSION}

The size of the labia minora as well as presenting symptoms should be taken into account, while planning labiaplasty in any age group, especially in adolescents.
Abetter classification system for labia minora hypertrophy and standardization regarding functional and cosmetic labiaplasty need to be established in this era of ever-increasing vulvovaginal surgeries.

Funding: No funding sources

Conflict of interest: None declared

Ethical approval: Not required

\section{REFERENCES}

1. Sakamoto H, Ichikawa G, Shimizu Y, Kikuchi A, Yamamoto T. Extreme hypertrophy of the labia minora. Acta Obstetricia et Gynecol Scandinavica. 2004;83(12):1225-6.

2. Ellsworth WA, Rizvi M, Lypka M, Gaon M, Smith B, Cohen B, et al. Techniques for labia minora reduction: an algorithmic approach. Aesthetic Plast Surg. 2010;34:105-10.

3. Pardo J, Solà V, Ricci P, Guilloff E. Laser labioplasty of labia minora. Int J Gynaecol Obstet. 2006;93:38 43.

4. Miklos JR, Moore RD. Labiaplasty of the labia minora: Patients' indications for pursuing surgery. J Sex Med. 2008;5:1492-5.

5. Oranges CM, Sisti A, Sisti G. Labia minora reduction techniques: a comprehensive literature review. Aesthet Surg J. 2015;35:419-31.

6. Lynch A, Marulaiah M, Samarakkody U. Reduction labioplasty in adolescents. J Pediatr Adolesc Gynecol. 2008;21:147-9.

7. Liao LM, Creighton SM. Requests for cosmetic genitoplasty: How should healthcare providers respond? BMJ. 2007;334:1090-2.

Cite this article as: Firdaus A, Chaudhary R. Labial hypertrophy as a cause for vulvae pruritis. Int $\mathrm{J}$ Reprod Contracept Obstet Gynecol 2020;9:1738-40. 